amino-acid analysis, Mr G. J. Hills for assistance in optical diffractometry, and Mr S. Frey for photographic assistance.
R. W. HORNE
D. R. Davies
K. NORTON
M. GURNEY-SMITH

John Innes Institute,

\section{Colney Lane,}

Norwich NOR $70 F$

Received January 15, 1971.

${ }^{1}$ Sager, R., and Palade, G. E., J. Biophys. Biochem. Cytol., 3, 463 (1957).

${ }^{2}$ Walne, P. L., Amer. J. Bot., 53, 908 (1966).

3 Walne, P. L., Amer. J. Bot., 54, 564 (1967).

4 Cavalier-Smith, T., thesis, Univ. London (1967).

5 Barnett, J. R., and Preston, R. D., Proc. Roy. Microsc. Soc., 4, 135 (1969)

6 Lewin, R. A., Owen, M. J., and Melnick, J. L., Exp. Cell Res., 2, 708 (1951).

7 Mühlethaler, K., Biochim. Biophys. Acta, 3, 527 (1949).

8 Horne, R. W., and Davies, D. R., Septième Congrès Intern. de Microscopie Electronique, Grenoble, 3, 117 (1970).

${ }^{9}$ Klug, A., and De Rosier, D. J., Nature, 212, 29 (1966).

10 Davies, D. R., and Plaskitt, A., Genet. Res., 17, 33 (1971).

$"$ Salton, M. R. J., The Bacterial Cell Wall, 42 (Elsevier, Amsterdam, 1964).

12 Gotelli, J. B., and Cleland, R., Amer. J. Bot., 55, 907 (1968).

13 Kosta, V., and Carpenter, F. H., J. Biol. Chem., 239, 1799 (1964).

14 Glauert, A. M., and Thornley, M. J., Ann. Rev. Microbiol., 23, 159 (1969).

\section{Wolffia arrhiza as a Possible Source of Inexpensive Protein}

THE development of new foods is vital to the needs of the rapidly expanding population in Asia. But apart from the necessity of being competitive in market price, they must be acceptable to the human palate, a requirement that has often frustrated attempts to introduce new foods. In this light, the improvement of production and processing of a commodity which is currently marketed for direct human consumption but on a small and inefficient scale has several advantages. Such a commodity is the aquatic plant, Wolffia arrhiza Wimm., Lemnaceae, known to have been used as a vegetable by the Burmese, Laotians and the people of northern Thailand for many generations. The local Thai name for the plant, "khainam", may be literally translated as eggs of the water and suggests the oval shape of the plant (length $1.5 \mathrm{~mm}$, width $1.0 \mathrm{~mm}$ ). Khai-nam is generally regarded as a poor people's food and has attracted little attention as a potentially significant source of human food. The species also occurs in India ${ }^{1}$, but no report has been made pertaining to its application as a food source in that country.

We have observed the native methods of cultivating Wolffia arrhiza and have analysed samples. Small scale cultivation by rain-fed open ponding methods is carried out by villagers living near provincial urban centres in northern Thailand. The $p \mathrm{H}$ of the water in all the ponds visited (more than 100) was between 6.5 and 7.0 , and most were small $\left(60-100 \mathrm{~m}^{2}\right)$ and shaded by bamboo groves. No chemical fertilizers or manures were added. In controlled laboratory conditions, Wolffia has been found to reproduce vegetatively by budding and to have a generation time of approximately 4 days $^{2,3}$. But natural conditions with higher light intensities and temperatures seem to be more conducive to growth. In practice, the plants are harvested at intervals of 3 to 4 days during which period the relatively small number of plants remaining from the previous harvest multiply into a thick mass of yellowish-green plants at the water's surface indicating that several generations may have arisen within 4 days. Longer time intervals between harvests invariably lead to lower yields and a product con- taining a significant portion of dead brownish individual plants which, being unattractive, fetch a low market price. A record of harvesting over a period of 4 months from randomly chosen ponds revealed that the average yield of fresh marketable plants (collectively containing an average of $4 \%$ dry matter) is $0.68 \mathrm{~kg} / \mathrm{m}^{2} /$ week.

In the climatic conditions of the town of Chiengmai in northern Thailand (lat. $19^{\circ} \mathrm{N}$, long. $99^{\circ} \mathrm{E}$ ), Wolffia arrhiza remains in its edible vegetative form between November and July. The inedible sexually reproducing form prevails between August and October. On the basis of a 9 month period of productivity the calculated annual yield is 265 tons/ha fresh weight or 10.5 tons/ha dry weight. The chemical composition and annual areal yields of Wolffia are listed and compared with conventional crop yields in Table 1.

Table 1 Proximate Analysis and Yields of Wolffia arrhiza in Comparison with Conventional Crops

\begin{tabular}{lccccccc}
\hline & $\begin{array}{c}\text { Wolffia, } \\
\text { dry }\end{array}$ & \multicolumn{5}{c}{ Average yield (kg/ha/year) } \\
$\begin{array}{l}\text { Com- } \\
\text { ponent }\end{array}$ & $\begin{array}{c}\text { Geight } \% \\
\text { wround- }\end{array}$ & Wolffia & Soybean & nut & Rice & Corn \\
Protein & 19.8 & 2,080 & 303 & 229 & 71 & 179 \\
Carbohy- & & & & & & \\
$\quad$ drate & 43.6 & 4,589 & 255 & 164 & 849 & 1,451 \\
Fats & 5.0 & 533 & 158 & 397 & 4 & 87 \\
Fibre & 13.3 & 1,398 & 44 & 21 & 3 & 40 \\
Ash & 18.3 & 1,928 & 41 & 20 & 5 & 24 \\
Water & 0 & 0 & 89 & 51 & 124 & 238 \\
$\quad$ Total & 100.0 & 10,528 & 890 & 882 & 932 & 1,772 \\
\hline
\end{tabular}

The protein nitrogen was determined by the Kjeldahl method. Fats were extracted by the Soxhlet technique using dichloromethane. The rice was converted from paddy to dehusked rice (ratio 0.66 ) and groundnut was converted from unshelled to shelled groundnut (ratio 0.60 ). We determined the composition of Wolffia; those of crops were computed from US Department of Agriculture data ${ }^{4}$. Other data on conventional crops were obtained from the Food and Agriculture Organization ${ }^{5}$.

In terms of annual yield, Wolffia produces more dry matter than the traditional crops grown in Thailand. The protein yield of Wolffia is several times greater than those of the local crops. So far, no attempts have been made to increase yields by improving growth conditions but studies will be undertaken to determine the effects of supplemental nutrients, controlled incident solar radiation, harvesting periodicity and mixing in batch and continuous outdoor conditions. Dependent variables will include growth rates, areal yields, proximate analyses of the product, water requirements, nutritional value, production economics and market potential. The research will be directed towards establishing optimum production conditions giving greater yields at lower costs. The naturally occurring species, Wolffia arrhiza, will be studied first because of its proven market and nutritional acceptability.

Department of Biology,

Krachang Bhanthumnavin

Faculty of Science,

Mahidol University,

Bangkok 4, Thailand

\section{Michael G. MCGarRY}

Division of Environmental Engineering, Asian Institute of Technology,

Bangkok 5, Thailand

Received March 12; revised April 29, 1971.

1 Fischer, C. E. C., in Flora of the Presidency of Madras, Part IX (edit. by Gamble, J. S.) (Adlard and Son, London, 1931).

2 Sakdisuwan, S., thesis, Chulalongkorn Univ., Bangkok (1967).

3 Vacharabhaya, M., thesis, Chulalongkorn Univ., Bangkok (1969).

4 Composition of Foods, Agricultural Handbook No. 8 (United States Department of Agriculture, Agricultural Research Service, Washington, 1963).

5 Production Yearbook, 23 (Food and Agriculture Organization, Rome, 1969). 